\title{
EP4 receptor stimulation down-regulates human eosinophil function
}

\author{
Petra Luschnig-Schratl $\cdot$ Eva M. Sturm $\cdot$ Viktoria Konya $\cdot$ Sonia Philipose $\cdot$ \\ Gunther Marsche · Eleonore Fröhlich • Claudia Samberger • Doris Lang-Loidolt • \\ Stefan Gattenlöhner · Irmgard Th. Lippe • Bernhard A. Peskar • \\ Rufina Schuligoi $\cdot$ Akos Heinemann
}

Received: 3 May 2010/Revised: 7 February 2011/Accepted: 15 February 2011/Published online: 2 March 2011

(C) The Author(s) 2011. This article is published with open access at Springerlink.com

\begin{abstract}
Accumulation of eosinophils in tissue is a hallmark of allergic inflammation. Here we observed that a selective agonist of the $\mathrm{PGE}_{2}$ receptor EP4, ONO AE1329 , potently attenuated the chemotaxis of human peripheral blood eosinophils, upregulation of the adhesion molecule $\mathrm{CD} 11 \mathrm{~b}$ and the production of reactive oxygen species. These effects were accompanied by the inhibition of cytoskeletal rearrangement and $\mathrm{Ca}^{2+}$ mobilization. The involvement of the EP4 receptor was substantiated by a selective EP4 antagonist, which reversed the inhibitory effects of $\mathrm{PGE}_{2}$ and the EP4 agonist. Selective kinase inhibitors revealed that the inhibitory effect of EP4 stimulation on eosinophil migration depended upon activation of PI 3-kinase and PKC, but not cAMP. Finally, we found that EP4 receptors are expressed by human eosinophils, and are also present on infiltrating leukocytes in inflamed
\end{abstract}

Electronic supplementary material The online version of this article (doi:10.1007/s00018-011-0642-5) contains supplementary material, which is available to authorized users.

P. Luschnig-Schratl · E. M. Sturm · V. Konya · S. Philipose .

G. Marsche · I. Th. Lippe · B. A. Peskar - R. Schuligoi

A. Heinemann $(\bowtie)$

Institute of Experimental and Clinical Pharmacology, Medical

University of Graz, Universitaetsplatz 4, 8010 Graz, Austria

e-mail: akos.heinemann@medunigraz.at

E. Fröhlich · C. Samberger

Center for Medical Research, Medical University of Graz,

Graz, Austria

D. Lang-Loidolt

Department of Otorhinolaryngology, Medical University

of Graz, Graz, Austria

S. Gattenlöhner

Institute of Pathology, Medical University of Graz, Graz, Austria human nasal mucosa. These data indicate that EP4 agonists might be a novel therapeutic option in eosinophilic diseases.

Keywords Eosinophils · Prostaglandins - Receptors · Chemotaxis $\cdot$ Reactive oxygen species $\cdot$ Degranulation

\author{
Abbreviations \\ BSA Bovine serum albumin \\ cAMP Cyclic adenosine monophosphate \\ COX Cyclooxygenase \\ CREB cAMP response element binding protein \\ EP E-type prostanoid receptor \\ ERK Extracellular signal-regulated kinase \\ FITC Fluorescein isothiocyanate \\ IL Interleukin \\ IP I-type prostanoid receptor \\ LT Leukotriene \\ PE Phycoerythrine \\ PG Prostaglandin \\ PI3K Phosphatidylinositol 3-kinase \\ PKA Protein kinase A \\ PKC Protein kinase $\mathrm{C}$ \\ PMA Phorbol 12-myristate 13-acetate \\ TP Thromboxane-type prostanoid receptor
}

\section{Introduction}

Eosinophils play a major role in late-phase reactions by releasing bronchoconstrictor mediators such as leukotriene (LT) $\mathrm{C}_{4}$ and other chemoattractants that cause further influx of inflammatory cells into the tissue, and immunoregulatory type-2 cytokines, interleukin (IL)-4, IL-5, IL-10, 
and IL-13 [1]. Mucosal damage in chronic asthma is associated with cytotoxic mediators that are released by activated eosinophils, including matrix metalloproteases, major basic protein, eosinophil cationic protein, eosinophil peroxidase and eosinophil-derived neurotoxin, leading to airway remodeling and angiogenesis in chronically inflamed tissue [2, 3]. Importantly, it was shown that asthmatic patients who receive treatment based on eosinophil counts in sputum have significantly fewer severe asthma exacerbations than patients treated according to standard management therapy [4]. Therefore, eosinophils are currently considered a major therapeutic target in allergic diseases and asthma [5], eosinophilic esophagitis [6], colitis ulcerosa [7], or hypereosinophilic syndrome [8].

$\mathrm{PGE}_{2}$ is the predominant cyclooxygenase (COX) product of airway macrophages, epithelial cells, and smooth muscle cells, and is regarded as a potent inflammatory mediator due to its effects on vasodilation, vascular permeability, and nociception. However, the role of $\mathrm{PGE}_{2}$ in allergic inflammation is less clear. In the asthmatic lung, $\mathrm{PGE}_{2}$ affects both airway smooth muscle and the inflammatory process: $\mathrm{PGE}_{2}$ causes bronchial relaxation [9] and inhibits allergen-induced bronchoconstriction [10], but it may also provoke bronchoconstrictor responses and cough in some individuals [11, 12] because of activation of C-fibers and reflex cholinergic pathways [13]. In rats and humans, $\mathrm{PGE}_{2}$ reduces allergen-induced airway eosinophilia [14, 15], attenuates anaphylactic mediator release from guinea-pig perfused lungs [16], abrogates eosinophil accumulation after passive cutaneous anaphylaxis in guinea pigs [17], and protects against bleomycin-induced pulmonary fibrosis in mice [18]. Conversely, eosinophil influx is exaggerated in COX-1 or COX-2 knockout mice $[19,20]$ and also in mice treated with selective COX-1 or COX-2 inhibitors [21]. At the cellular level, $\mathrm{PGE}_{2}$ has been found to attenuate immunoglobulin-dependent degranulation and $\mathrm{LTC}_{4}$ biosynthesis of eosinophils [22], and agonist-induced CD11b upregulation and L-selectin shedding in eosinophils and neutrophils [23]. In contrast, $\mathrm{PGE}_{2}$ is anti-apoptotic for eosinophils [24], while its analogue misoprostol inhibits eosinophil survival in vitro [25].

The biological effects of $\mathrm{PGE}_{2}$ are mediated through four different $G$ protein-coupled heptahelical receptors, termed EP1, EP2, EP3, and EP4 [26]. Each of these receptors has a distinct pharmacological signature based on its selectivity towards synthetic $\mathrm{PGE}_{2}$ analogs and intracellular signal transduction. Stimulation of the EP1 receptor results in $\mathrm{G}_{\mathrm{q}}$-mediated activation of phospholipase $\mathrm{C}$ and phosphatidylinositol hydrolysis, elevation of the intracellular $\mathrm{Ca}^{2+}$ level, and causes the activation of protein kinase $\mathrm{C}$ (PKC) [27]. The EP3 receptor exists as a number of splice variants displaying various degrees of constitutive activity. EP3 signals through activation of a $\mathrm{G}_{\mathrm{i}}$ protein to inhibit adenylyl cyclase leading to reduction of intracellular cyclic adenosine monophosphate (cAMP) generation and elevation of intracellular-free $\mathrm{Ca}^{2+}$ levels. However, isoforms of EP3 also have the capacity to enhance cAMP formation by coupling to $G_{s}$ protein [28]. In contrast, stimulation of EP2 and EP4 receptors usually increases intracellular cAMP levels and activates protein kinase A (PKA) through $\mathrm{G}_{\mathrm{s}}$ protein. Interestingly, EP2 receptor stimulation can also trigger $\mathrm{Ca}^{2+}$ currents in a cAMP-dependent/PKA-independent manner [29].

We recently described that stimulation of EP2 receptors attenuates eosinophil trafficking [30], and we also obtained some preliminary information on a potential role of EP4 receptors in the regulation of eosinophil function. Therefore, in this study we investigated the expression, function, and signaling of EP4 receptors in eosinophils in detail and suggest that EP4 receptors are even more substantially involved in the regulation of eosinophil effector functions as compared to EP2 receptors. EP4 agonists might hence be novel therapeutic options for the treatment of eosinophilic diseases.

\section{Materials and methods}

\section{Chemicals}

All laboratory reagents were from Sigma (Vienna, Austria), unless specified. Assay buffer used in all experiments was made from Dulbecco's modified phosphate-buffered saline (PBS; with $0.9 \mathrm{mM} \mathrm{Ca}^{2+}$ and $0.5 \mathrm{mM} \mathrm{Mg}^{2+}$; Invitrogen, Vienna, Austria), $0.1 \%$ bovine serum albumin (BSA); $10 \mathrm{mM}$ HEPES and $10 \mathrm{mM}$ glucose, $\mathrm{pH}$ 7.4. CellFix and FACS-Flow were from Becton-Dickinson (Vienna, Austria). Human eotaxin and IL-8 were from Peprotech (London, UK). $\mathrm{PGD}_{2}, \mathrm{PGE}_{2}$, the $\mathrm{EP} 2$ receptor agonist butaprost, the EP1/EP3 receptor agonist sulprostone, the EP4 receptor antagonist GW627368X and the EP1/I-type prostanoid (IP) receptor agonist iloprost were from Cayman Chemicals (Ann Arbor, MI, USA). Polyclonal rabbit anti-human EP4 receptor antibodies directed against the $\mathrm{C}$ terminus of the receptor were provided by Sigma and Cayman. Goat antibody against eosinophil peroxidase was from Santa Cruz Biotechnology (Heidelberg, Germany). Mouse anti-eosinophil peroxidase antibody was supplied by Becton-Dickinson. Donkey anti-mouse Alexa Fluor 555 and donkey anti-rabbit Alexa Fluor 488 antibodies were obtained from Invitrogen. Rabbit and goat control IgG was from Linaris (Wertheim-Bettingen, Germany). The adenylyl cyclase inhibitor SQ22536, the PI3K inhibitor LY294002 and the PKC inhibitor chelerythrine were supplied from Biomol (Hamburg, Germany). The EP4 agonist 
ONO AE1-329 (2-[3-[(1R,2S,3R)-3-hydroxy-2-[(E,3S)-3hydroxy-5-[2-(methoxymethyl)phenyl]pent-1-enyl]-5-oxocyclopentyl]sulfanylpropylsulfanyl]acetic acid) and the EP4 antagonist ONO AE3-208 (2-[[2-[2-(2-methylnaphthalen1-yl)propanoylamino]phenyl]methyl]benzoic acid) were a kind gift from ONO Pharmaceutical (Osaka, Japan). ONO AE1-329 has been shown in competitive radioligand binding assays to selectively bind to EP4 receptors $\left(K_{\mathrm{i}}=9.7 \mathrm{nM}\right)$ relative to the $\mathrm{EP} 1, \mathrm{EP} 2$, and $\mathrm{EP} 3$ receptors $\left(K_{\mathrm{i}}=\right.$ $>10,000,>2,000$ and $>1,000 \mathrm{nM}$, respectively) [31]. GW627368X (4-(4,9-diethoxy-1,3-dihydro-1-oxo-2H-benz [f]isoindol-2-yl)- $N$-(phenyl sulfonyl)-benzeneacetamide) exhibits a $K_{\mathrm{i}}$ value of $100 \mathrm{nM}$ towards EP4 and $158 \mathrm{nM}$ to thromboxane-type prostanoid (TP) receptors, with $K_{\mathrm{i}}$ values above $10,000 \mathrm{nM}$ for all other prostanoid receptors [32]. The $K_{\mathrm{i}}$ values of ONO AE3-208 are 1.3, 30, 790, 2,400 nM for EP4, EP3, F-type prostanoid (FP) receptor, and TP, respectively, and more than $10,000 \mathrm{nM}$ for other prostanoid receptors [33].

\section{Preparation of human leukocytes}

This study was approved by the Ethics Committee of the Medical University of Graz. Prior to blood sampling from healthy non-atopic volunteers, all donors signed an informed-consent form. Platelet-rich plasma was removed by centrifugation of citrated whole blood. Erythrocytes were removed by dextran sedimentation. High-density polymorphonuclear leukocytes (PMNL, containing neutrophils and eosinophils) were isolated by Histopaque gradient centrifugation. Any erythrocyte contamination of the PMNL pellet was removed by hypotonic shock lysis as described previously [34]. Purified eosinophil preparations were obtained by negative magnetic selection using antibody cocktails (CD2, CD14, CD16, CD19, CD56, and glycophorin A) and colloidal magnetic particles from StemCell Technologies (Vancouver, Canada). Resulting purity and viability was typically $>97 \%$.

\section{Chemotaxis}

Migration of eosinophils was determined in 48-well microBoyden chemotaxis chambers. Purified eosinophils were resuspended in assay buffer at $2 \times 10^{6}$ cells $/ \mathrm{ml}$ and $50 \mu \mathrm{l}$ of the cell-suspension were loaded into the top wells of the chamber which were separated from the bottom wells by a 5 - $\mu \mathrm{m}$ pore-size polyvinylpyrrolidone-free polycarbonate filter. Thirty microliters of assay buffer or agonists were placed into the bottom wells of the chamber. Baseline migration was determined in wells containing only assay buffer. The chamber was incubated at $37^{\circ} \mathrm{C}$ for $1 \mathrm{~h}$ in a humidified incubator. The membrane was subsequently removed and migrated cells were enumerated by a
FACSCalibur flow cytometer (Becton-Dickinson, Mountain View, CA, USA) [35].

Leukocyte shape change assay

Preparations of polymorphonuclear leukocytes (PMNL; containing eosinophils and neutrophils) or purified eosinophils were resuspended in assay buffer and aliquots of the cell-suspension were mixed with agonists at a final volume of $100 \mu \mathrm{l}$ and stimulated for $4 \mathrm{~min}$ at $37^{\circ} \mathrm{C}$. Cells were transferred to ice and $250 \mu$ of ice-cold fixative solution was added to terminate the reaction. Changes in the cell shape were estimated immediately by the increase of forward scatter using a FACSCalibur flow cytometer (BectonDickinson, Mountain View, CA, USA). Eosinophils were distinguished from neutrophils according to granularity (side scatter) and by their autofluorescence.

Respiratory burst

Purified eosinophils $\left(5 \times 10^{5}\right.$ cells $\left./ \mathrm{ml}\right)$ were stimulated with agonists in the presence of $1 \mu \mathrm{M}$ dihydrorhodamine123 for $20 \mathrm{~min}$ at $37^{\circ} \mathrm{C}$ and then fixed with $150 \mu \mathrm{l}$ of icecold $2.5 \%$ Cellfix. Respiratory burst of eosinophils was immediately quantified by flow cytometry as the increase of fluorescence in the FL-1 channel due to the oxidization by reactive oxygen species of the non-fluorescent dye dihydrorhodamine-123 into fluorescent rhodamine-123 [36]. Responses were expressed as percent changes from a control sample incubated with buffer alone.

\section{Upregulation of eosinophil CD11b expression}

Polymorphonuclear leukocyte preparations were incubated with agonists for $30 \mathrm{~min}$ at $37^{\circ} \mathrm{C}$ and then stained with anti-CD11b (FITC) and anti-CD16 (PE-Cy5) antibodies. CD11b expression on CD16-negative eosinophils was quantified by flow cytometry and expressed as percent of the maximal control response (i.e., in the absence of a prostanoid).

\section{Calcium ion flux}

Intracellular $\mathrm{Ca}^{2+}$ levels in eosinophils were analyzed by flow cytometry as described previously [37]. Polymorphonuclear leukocyte preparations were treated with $2 \mu \mathrm{M}$ of the acetoxymethyl ester of Fluo-3 in the presence of $0.02 \%$ pluronic $\mathrm{F}-127$ for $60 \mathrm{~min}$ at room temperature before being washed with PBS without $\mathrm{Ca}^{2+}$ and $\mathrm{Mg}^{2+}$. Cells were then stained with anti-CD16 (PE) and resuspended in assay buffer at $3 \times 10^{6}$ cells $/ \mathrm{ml}$. Changes in intracellular $\mathrm{Ca}^{2+}$ levels were detected by flow cytometry as the increase of the fluorescence of the $\mathrm{Ca}^{2+}$ sensitive dye 
Fluo-3 in the FL1-channel. Eosinophils were identified as CD16-negative cells.

Flow cytometric analysis of EP receptor expression

Expression of EP1, EP2, EP3, and EP4 receptors on human peripheral blood eosinophils was quantified by indirect immunofluorescence flow cytometry. As the EP antibodies had been raised against the intracellular $\mathrm{C}$ terminus of the $\mathrm{EP}$ receptors, aliquots of isolated eosinophils were first permeabilized with Fix\&Perm solution (ADG Bio Research; Kaumberg, Austria) for $15 \mathrm{~min}$ at room temperature. Samples were then treated with the following reagents for $30 \mathrm{~min}$ each on ice with appropriate washing steps in between: Ultra V Block (Labvision, Westinghouse, CA, USA) to block Fc receptors; $20 \mu \mathrm{g} / \mathrm{ml}$ polyclonal EP1, EP2, EP3 or EP4 antibody or $20 \mu \mathrm{g} / \mathrm{ml}$ polyclonal rabbit isotype control antibody; and $4 \mu \mathrm{g} / \mathrm{ml}$ anti-rabbit IgG secondary antibody conjugated with Alexa Fluor-488. After adding the fixative solution the cells were analyzed on a FACSCalibur flow cytometer (BD Biosciences).

\section{Western blot of EP4 receptors}

Purified eosinophils were lysed in a buffer containing $50 \mathrm{mM}$ Tris- $\mathrm{HCl}, 25 \mathrm{mM} \mathrm{KCl}, 5 \mathrm{mM} \mathrm{MgCl}_{2}$, and $0.2 \%$ Nonidet P-40 supplemented with protease inhibitors (Roche; Basel, Switzerland) and centrifuged at 10,000 rpm for $10 \mathrm{~min}$ at $4^{\circ} \mathrm{C}$. Bradford protein assay (Bio-Rad; Vienna, Austria) was performed to determine the protein content in the supernatants. Protein samples $(50 \mu \mathrm{g})$ were separated by SDS-polyacrylamide gel electrophoresis on a gradient gel (4-20\%) and protein bands were blotted onto polyvinylidenefluoride (Bio-Rad) membrane. Target proteins were immunochemically detected using a polyclonal rabbit anti-human EP4 antibody $(20 \mu \mathrm{g} / \mathrm{ml})$. Bands were visualized with horseradish peroxidase-conjugated goat anti-rabbit IgG ( $4 \mu \mathrm{g} / \mathrm{ml}$; Pierce, Rockford, IL, USA) and Amersham ECL Plus detection reagents (GE Healthcare; Vienna, Austria).

\section{Immunohistochemistry of EP4 receptors}

Paraffin blocks of nasal polyps that had been previously classified by a pathologist to contain eosinophil infiltrates were obtained from the Tissue Bank of the Medical University of Graz as approved by the local ethics committee. Five-micrometer sections were deparaffinized, antigen retrieval was performed in DakoCytomation Target Retrieval Solution (Glostrup, Denmark) for $10 \mathrm{~min}$ at $120^{\circ} \mathrm{C}$, and sections were blocked with $1 \%$ BSA and $0.05 \%$ Triton $\mathrm{X}-100$ in PBS for $30 \mathrm{~min}$ at room temperature. The samples were incubated overnight with a rabbit anti-human EP4 antibody (1.7 $\mu \mathrm{g} / \mathrm{ml}$, Sigma) or rabbit control IgG antibody. After washing, the bound antibody was detected using the Liquid DAB + Substrate Chromogen System (Dako Cytomation). Staining of eosinophil peroxidase-positive cells was performed with a polyclonal goat antibody against eosinophil peroxidase $(20 \mu \mathrm{g} / \mathrm{ml})$ or control antibody for $30 \mathrm{~min}$ at room temperature. After washing, the bound antibody was then visualized with the EnVision Permanent Red (Dako Cytomation). Slides were finally counterstained with Mayer's hematoxylin. Sections were visually examined with a Zeiss Axiophot microscope (Zeiss, Oberkochen, Germany) and a Zeiss Plan-Neofluar $\times 20 / 05$ lens. Photographs were taken with a CoolSNAP camera $(1392 \times 1040$ pixels; Photometrics, Tucson, AZ, USA) and a RGB Tunable Micro*color filter (CRI, Woburn, MA, USA). Further processing of images was performed with MCID-M2 software (Imaging Research Inc., Brock University, St. Catharines, Ontario, Canada) for additional white balance, contrast, and brightness adjustments.

Double immunofluorescence stainings of eosinophil peroxidase and EP4 were performed as described [38] with incubation times of 10 and $50 \mathrm{~min}$, respectively, using the following antibodies: mouse-anti-human eosinophil peroxidase antibody; rabbit anti-human EP4 antibody (12.5 $\mu \mathrm{g} /$ $\mathrm{ml}$, Sigma); and donkey anti-mouse Alexa Fluor 555 or donkey anti-rabbit Alexa Fluor 488 (both $0.5 \mu \mathrm{g} / \mathrm{ml}$ ). Images were taken with a confocal laser scanning microscope (Leica TCS SP2; Leica, Bensheim, Germany) using Leica Confocal Software version 2.61 Build 1537.

\section{Statistical analyses}

Data are shown as mean \pm SEM for $n$ observations. Comparisons of groups were performed using one-way ANOVA or two-way ANOVA for repeated measurements followed by Holm-Sidak post-hoc test to determine the levels of significance for each group. Probability values of $p<0.05$ were considered as statistically significant.

\section{Results}

Involvement of EP4 receptors in the $\mathrm{PGE}_{2}$-induced attenuation of eosinophil migration

We showed recently that $\mathrm{PGE}_{2}$ and the EP2 agonist butaprost attenuate the migratory responsiveness of human eosinophil granulocytes [30]. Here we investigated the potential role of EP4 receptors in eosinophil function. For that purpose, we pretreated purified human eosinophils with the EP4 receptor antagonists GW627368X (1 or $10 \mu \mathrm{M})$ or ONO AE3-208 (100 $\mathrm{nM})$ or their vehicle for $15 \mathrm{~min}$ at $37^{\circ} \mathrm{C}$, and then mixed them with various concentrations of 
$\mathrm{PGE}_{2}$ (3-100 nM). Migration towards eotaxin (1 nM) was determined thereafter. $\mathrm{PGE}_{2}$ led to a decrease of eosinophil migration in a concentration-dependent manner; at the highest concentration of $\mathrm{PGE}_{2}(100 \mathrm{nM})$ migration was reduced by more than $70 \%$. The inhibitory effect of $\mathrm{PGE}_{2}$ was markedly attenuated by the selective EP4 receptor antagonists GW627368X (Fig. 1a) or ONO AE3-208 ( $n=4$, data not shown). In agreement with these findings, we also observed that the EP4-selective agonist ONO AE1329 (3-100 nM) mimicked the effect of $\mathrm{PGE}_{2}$ at inhibiting eosinophil migration towards eotaxin $(1 \mathrm{nM})$ and $\mathrm{PGD}_{2}$ $(30 \mathrm{nM})$ with the same efficacy and potency as $\mathrm{PGE}_{2}$ (Fig. 2a, b).

The expression of EP4 receptors on human eosinophils was investigated by indirect flow-cytometric immunostaining and Western blot. Eosinophils showed high positive staining for EP4 receptors in flow cytometry (Fig. 1b). The specificity of the EP4 staining was confirmed by applying the appropriate isotype control antibody, which gave considerably lower staining than the EP4 receptor antibody (Fig. 1b). EP4 receptors were also detected on neutrophils. EP4 expression was confirmed by Western-blot analysis using the same EP4 antibody in three eosinophil samples from different donors and one neutrophil preparation (Fig. 1c). The EP4 receptor has previously been described both as a $65-$ or a $52-\mathrm{kDa}$ protein $[39,40]$. Our data show that it is the $65-\mathrm{kDa}$ variant that is expressed by eosinophils. Moreover, we were able to confirm the expression of the other EP receptor isoforms (EP1, EP2, EP3) on circulating eosinophils by using indirect flow-cytometric staining (Suppl. Fig. S1). These data demonstrated that EP4 receptors on eosinophils negatively control locomotion.

EP4 receptors attenuate the migration of eosinophils via $\mathrm{PI} 3 \mathrm{~K}$ and $\mathrm{PKC}$

We next investigated the potential pathways by which EP4 receptors control eosinophil chemotaxis. Elevated concentrations of intracellular cAMP are supposed to confer attenuation of eosinophil migration and EP4 receptors have been shown to stimulate adenylyl cyclase [26]. Purified eosinophils were pretreated with the adenylyl cyclase inhibitor SQ22536 $(10 \mu \mathrm{M})$ or the appropriate vehicle for $30 \mathrm{~min}$ at $37^{\circ} \mathrm{C}$ before they were mixed with varying
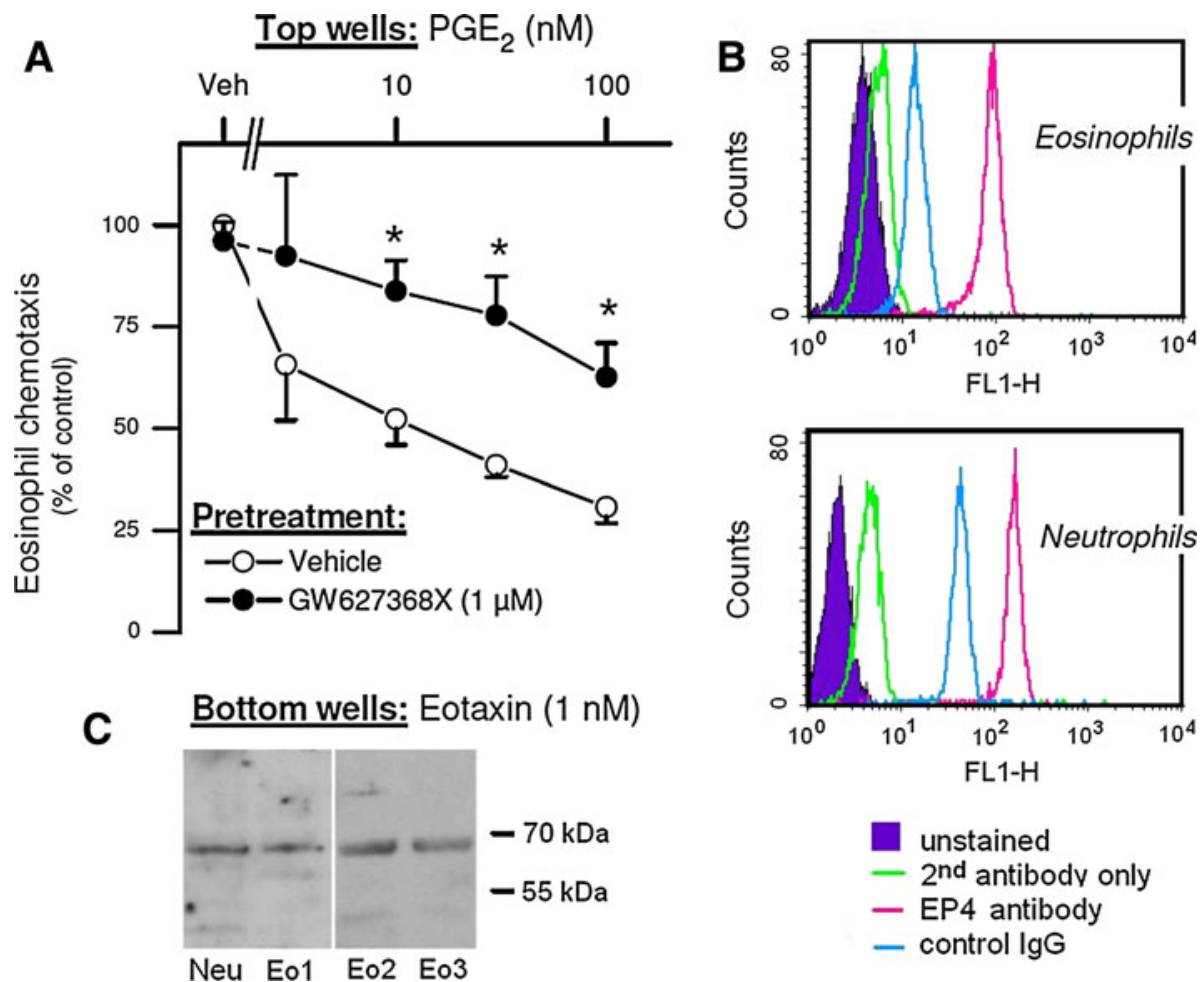

Fig. 1 EP4 receptors are expressed by human eosinophils and mediate the inhibitory effect of $\mathrm{PGE}_{2}$ on migration. a Purified eosinophils were pretreated with the EP4 receptor antagonist GW627368X or vehicle, mixed with $\mathrm{PGE}_{2}$ and loaded into the top wells of a microBoyden chamber. Cells were allowed to migrate towards eotaxin in the bottom wells. Responses were expressed as percent of the control response, i.e., to eotaxin only. b EP 4 receptor

expression on purified eosinophils or neutrophils was determined with indirect flow cytometric staining. The histograms show flow cytometric analyses representative of three experiments with different donors. c Western blot showing EP4 expression in one neutrophil sample $(\mathrm{Neu})$ and three different eosinophil preparations (Eol-3). Data are shown as mean \pm SEM, $n=5$. $* p<0.05$ versus vehicle 

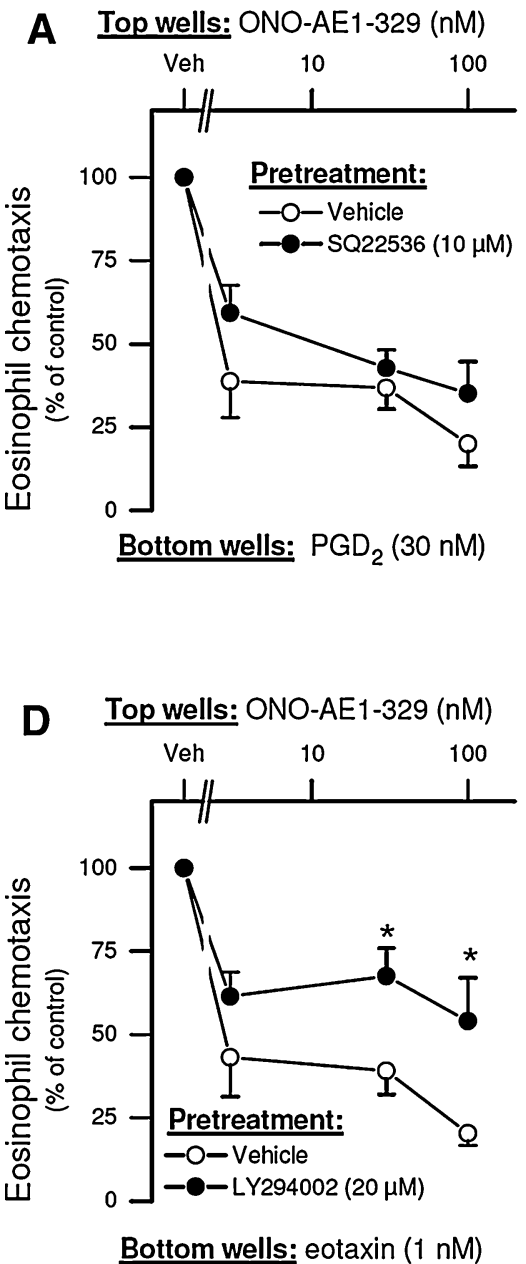
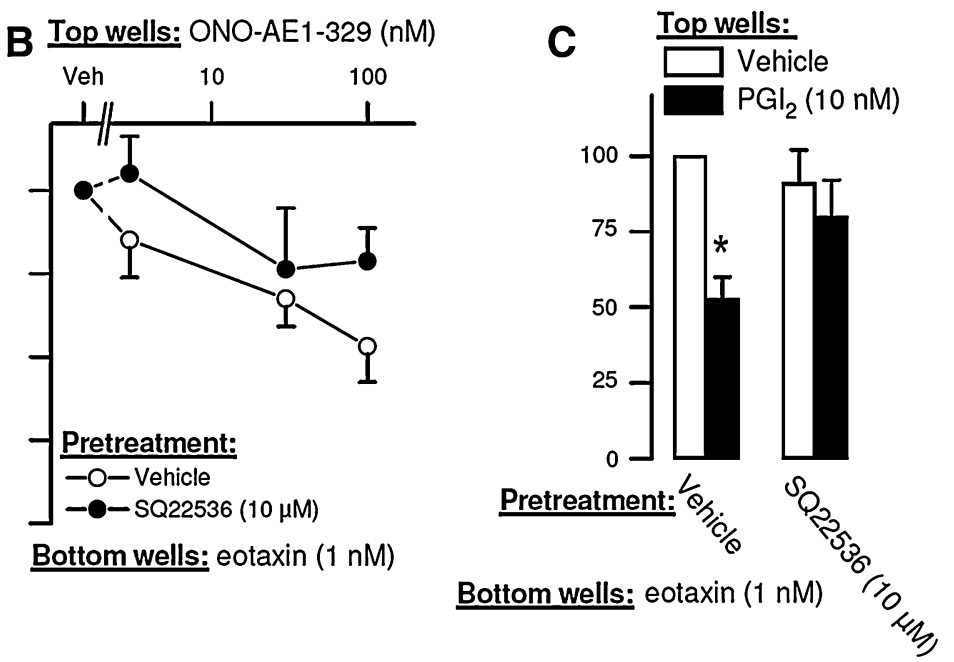

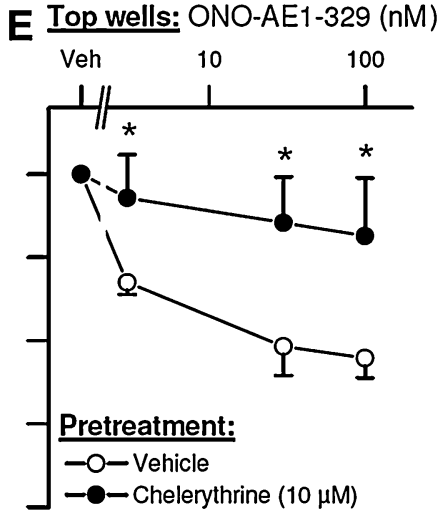

Bottom wells: eotaxin ( $1 \mathrm{nM})$

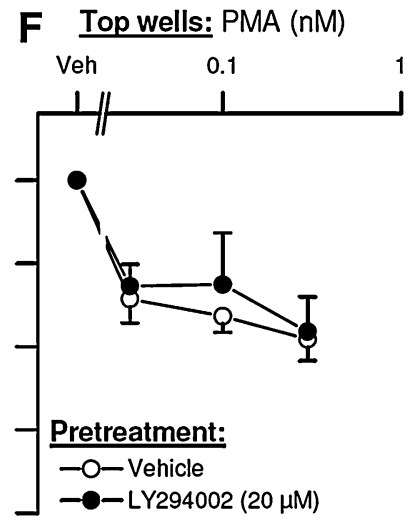

Bottom wells: eotaxin (1 nM)
Fig. 2 The EP4 receptor mediates the attenuation of eosinophil migration via PI3K and PKC but not via PKA. a-c Purified eosinophils were pretreated with vehicle or the adenylyl cyclase inhibitor SQ22536, mixed with varying concentrations of the EP4 receptor agonist ONO AE1-329 or $\mathrm{PGI}_{2}$, and migration towards $\mathrm{PGD}_{2}$ or eotaxin was determined. $\mathbf{d}$, f Purified eosinophils were pretreated with the PI3K inhibitor LY294002 or its vehicle, mixed with varying concentrations of the EP4 receptor agonist ONO AE1-329 or the PKC

concentrations of the EP4 receptor agonist ONO AE1-329 and were allowed to migrate towards $\mathrm{PGD}_{2}(30 \mathrm{nM})$ or eotaxin $(1 \mathrm{nM})$, respectively. Unexpectedly, inhibition of adenylyl cyclase could not prevent the inhibitory effect of the EP4 receptor agonist ONO AE1-329 (Fig. 2a, b). In contrast, the same concentration of SQ22536 effectively reversed the effect of $\mathrm{PGI}_{2}(100 \mathrm{nM})$ of attenuating eosinophil migration towards eotaxin (1 nM, Fig. 2c).

$\mathrm{PI} 3 \mathrm{~K}$ and $\mathrm{PKC}$ are involved in the regulation of eosinophil responses to chemoattractants [41, 42], and we have found that the $\mathrm{PGE}_{2}$-induced inhibition of eosinophil chemotaxis was prevented by inhibitors of PI3K and PKC [30]. Therefore, we wondered whether PI3K and PKC might be linked to EP4 activation and mediated the attenuation of activator agent PMA, and migration towards eotaxin was determined. e Purified eosinophils were pretreated with the PKC inhibitor chelerythrine or vehicle, mixed with varying concentrations of the EP4 receptor agonist ONO AE1-329, and migration towards eotaxin was determined. Responses were expressed as percent of the control response, e.g., eotaxin alone. Data are shown as mean \pm SEM.; $n=4,5 . * p<0.05$ versus vehicle

eosinophil chemotaxis. To this end, cells were pretreated with the PI3K inhibitor LY294002 $(20 \mu \mathrm{M})$, the PKC inhibitor chelerythrine $(10 \mu \mathrm{M})$ or the respective vehicle for $20 \mathrm{~min}$ at $37^{\circ} \mathrm{C}$. Next, the cells were mixed with varying concentrations of ONO AE1-329 and were then allowed to migrate towards eotaxin $(1 \mathrm{nM})$. The inhibitory effect of the EP4 receptor agonist on eosinophil migration was significantly reduced by the PI $3 \mathrm{~K}$ inhibitor and was almost completely prevented by pretreatment with the PKC inhibitor (Fig. 2d, e). Direct activation of PKC with phorbol 12-myristate 13-acetate (PMA) also resulted in a decrease of eosinophil migration towards eotaxin but this response was not affected by pretreatment of the cells with the PI3K inhibitor LY294002 (Fig. 2f). These data suggested that 
both PI3K and PKC, but not the adenylyl cyclase/cAMP pathway, are involved in the signaling of the EP4-mediated attenuation of eosinophil migration.

$\mathrm{PGE}_{2}$ inhibits $\mathrm{Ca}^{2+}$ flux and shape change of eosinophils via EP4 receptors

It is known that chemoattractants like eotaxin or $\mathrm{PGD}_{2}$ induce $\mathrm{Ca}^{2+}$ mobilization in eosinophil granulocytes, a response that is essential for effector functions such as respiratory burst, degranulation, and mediator release [43]. Therefore, we investigated the influence of $\mathrm{PGE}_{2}$ on the chemoattractant-induced $\mathrm{Ca}^{2+}$ mobilization. Eosinophil $\mathrm{Ca}^{2+}$ flux, as induced by eotaxin $(1 \mathrm{nM})$ or $\mathrm{PGD}_{2}(3 \mathrm{nM})$, was attenuated in a concentration-dependent manner by $\mathrm{PGE}_{2}$ (3-100 nM; Fig. 3a). Similarly, the EP4 agonist ONO AE1-329 (3-100 nM) led to a decrease in $\mathrm{Ca}^{2+}$ influx in eosinophils (Fig. 3a). To elucidate the role of EP receptor subtypes we used the EP2 receptor agonist butaprost, the EP1/EP3 receptor agonist sulprostone, the EP4 agonist ONO AE1-329 and the IP/EP1 receptor agonist iloprost. Out of these compounds only $\mathrm{PGE}_{2}$ and ONO AE1-329 showed a significant attenuation of $\mathrm{Ca}^{2+}$ flux induced by eotaxin or $\mathrm{PGD}_{2}$ in eosinophils (Fig. 3b).

We further investigated the influence of $\mathrm{PGE}_{2}$ on the $\mathrm{Ca}^{2+}$ mobilization induced by higher concentrations of eotaxin. Stimulation with eotaxin $(1,3$ and $10 \mathrm{nM})$ concentration-dependently increased the $\mathrm{Ca}^{2+}$ flux in eosinophils. These $\mathrm{Ca}^{2+}$ responses were attenuated over the entire range of eotaxin concentrations by $\mathrm{PGE}_{2}$, and the extent of inhibition likewise depended on the concentration of $\mathrm{PGE}_{2}$ (3-300 nM; Fig. 4a). To further substantiate the role of $\mathrm{EP} 4$ receptors in the $\mathrm{PGE}_{2}$-mediated inhibition of $\mathrm{Ca}^{2+}$ mobilization, we pretreated the cells with the EP4 receptor antagonist ONO AE3-208 $(100 \mathrm{nM})$ for $15 \mathrm{~min}$ at $37^{\circ} \mathrm{C}$ before the effects of $\mathrm{PGE}_{2}$ and the EP4 receptor agonist ONO AE1-329 (30 $\mathrm{nM}$ each) on the eotaxin-induced $\mathrm{Ca}^{2+}$ flux were determined. In fact, ONO AE3-208 reversed the attenuation both by $\mathrm{PGE}_{2}$ and $\mathrm{ONO}$ AE1-329 of the eotaxininduced $\mathrm{Ca}^{2+}$ mobilization (Fig. 4b, c). Similar observations were made with the alternative EP4 antagonist GW627368X (data not shown, $n=5$ ).

Besides eliciting an increase in free intracellular $\mathrm{Ca}^{2+}$, stimulation with chemoattractants results in rapid reorganization of the cytoskeleton and shape change of granulocytes, which can be detected by flow cytometry [44]. These responses are important prerequisites for granulocyte adhesion, polarization, locomotion, and degranulation. To elucidate the role of $\mathrm{PGE}_{2}$ in chemoattractant-induced shape change responses, we mixed eosinophils with various concentrations of $\mathrm{PGE}_{2}$ or its vehicle and induced eosinophil shape change with $\mathrm{PGD}_{2}(0.06-20 \mathrm{nM})$. Similar to our results regarding migration and $\mathrm{Ca}^{2+}$ mobilization, we found
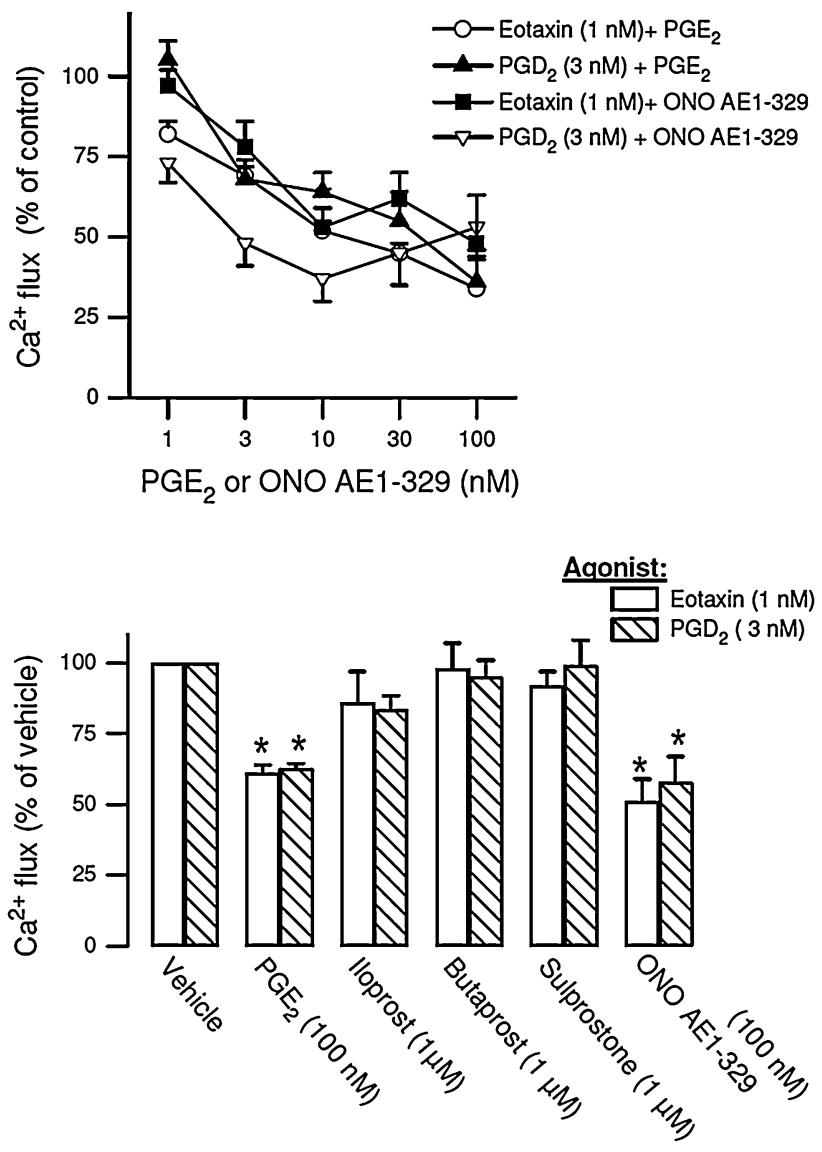

Fig. $3 \mathrm{PGE}_{2}$ attenuates the chemoattractant-induced $\mathrm{Ca}^{2+}$ flux in eosinophils. a Polymorphonuclear leukocyte preparations were mixed with vehicle, $\mathrm{PGE}_{2}$, or the EP4 agonist ONO AE1-329, and $\mathrm{Ca}^{2+}$ flux was induced with eotaxin or $\mathrm{PGD}_{2}$ in eosinophils. b Polymorphonuclear leukocyte preparations were mixed with vehicle, $\mathrm{PGE}_{2}$, the IP/ EP1 receptor agonist iloprost, the EP2 receptor agonist butaprost, the EP1/EP3 receptor agonist sulprostone, or the EP4 agonist ONO AE1329 , and $\mathrm{Ca}^{2+}$ flux was elicited with eotaxin or $\mathrm{PGD}_{2} \cdot \mathrm{Ca}^{2+}$ flux was recorded with flow cytometry as increase in fluorescence in FL-1. Eosinophils were distinguished from neutrophils as CD16-negative cells. Responses were expressed as percent of the control response, i.e., in the absence of a prostanoid. Data are shown as mean \pm SEM.; $n=4-8 . * p<0.05$ versus vehicle

that $\mathrm{PGE}_{2}$ inhibited eosinophil shape change in a concentration-dependent fashion with maximum attenuation at a concentration of $100 \mathrm{nM} \mathrm{PGE}_{2}$ (Fig. 5a). In further experiments we investigated the involvement of the different EP receptor subtypes by pretreating the cells with the EP2 receptor agonist butaprost, the EP1/EP3 receptor agonist sulprostone and the IP/EP1 receptor agonist iloprost. Unlike $\mathrm{PGE}_{2}$ none of these EP receptor agonists was able to inhibit $\mathrm{PGD}_{2}$ induced eosinophil shape change (Fig. 5b), which suggested the involvement of the EP4 receptor in this $\mathrm{PGE}_{2}-$ induced effect. In fact, pretreatment of eosinophils with the EP4 receptor antagonist ONO AE3-208 (100 nM) or GW627368X $(10 \mu \mathrm{M})$ before being mixed with $\mathrm{PGE}_{2}$ $(30 \mathrm{nM})$ or the EP4 receptor agonist ONO AE1-329 (30 nM) 
Fig. 4 EP4 receptors mediate the $\mathrm{PGE}_{2}$-induced inhibition of $\mathrm{Ca}^{2+}$ flux in eosinophils. a Polymorphonuclear leukocyte preparations were mixed with vehicle, or different concentrations of $\mathrm{PGE}_{2}$, and $\mathrm{Ca}^{2+}$ flux was elicited with eotaxin. b, c Polymorphonuclear leukocyte preparations were pretreated with the EP4 antagonist ONO AE3-208 or vehicle, then mixed with vehicle, $\mathrm{PGE}_{2}$ or the EP4 agonist ONO AE1-329, and $\mathrm{Ca}^{2+}$ flux was induced with eotaxin. $\mathrm{Ca}^{2+}$ flux was recorded by flow cytometry as increases in fluorescence in FL-1.

Eosinophils were distinguished from neutrophils as CD16negative cells. Responses were expressed as percent of the maximum control response, i.e., in the absence of a prostanoid. Data are shown as mean \pm SEM.; $n=6-12$. $* p<0.05$ versus vehicle
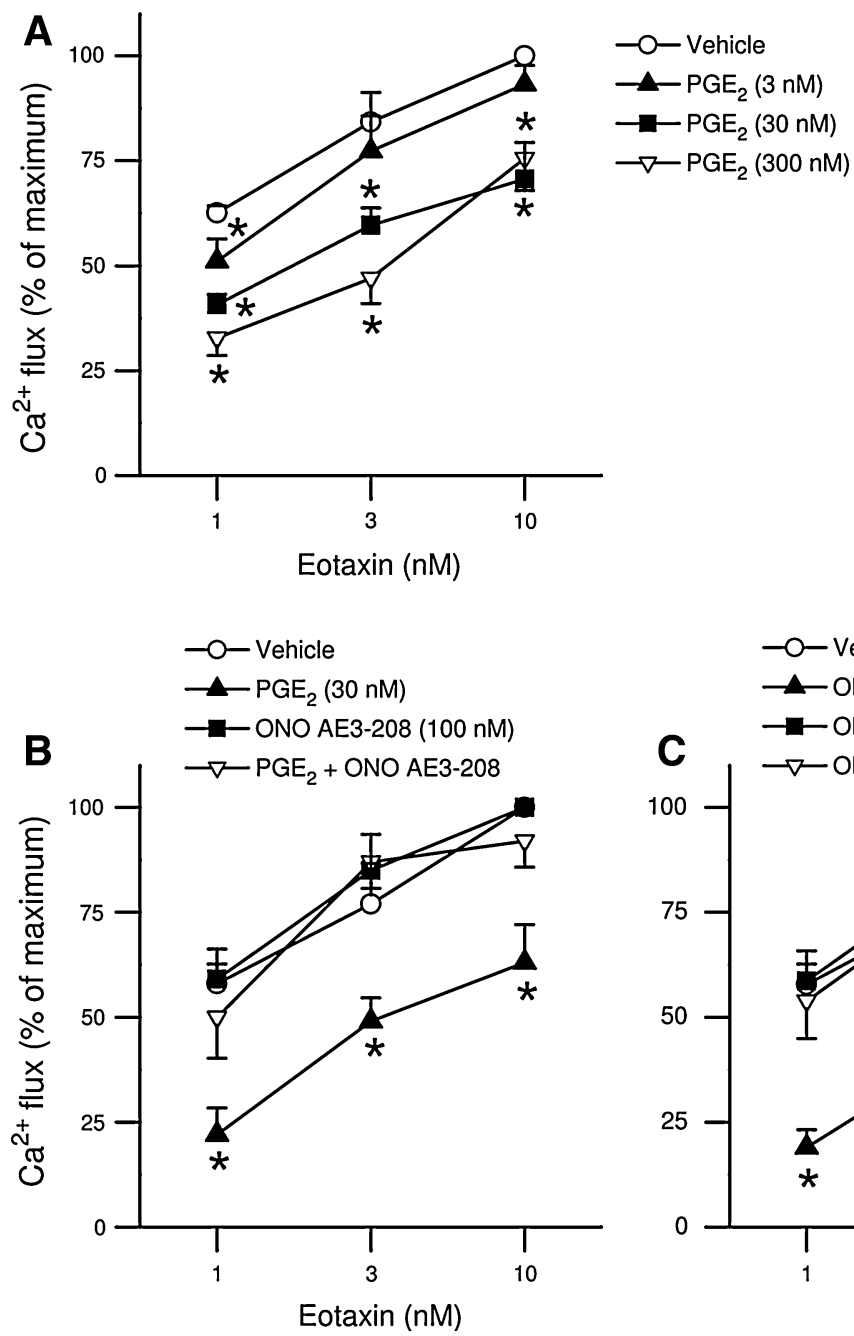

almost completely reversed the inhibitory effects of $\mathrm{PGE}_{2}$ and ONO AE1-329 on shape change responses to eotaxin (Fig. 5c, d). These data demonstrated that it is the EP4 receptor subtype that exclusively mediates the $\mathrm{PGE}_{2}-$ induced attenuation of eosinophil $\mathrm{Ca}^{2+}$ mobilization and shape change.

Further on, we determined the role of neutrophil granulocytes in the EP4-mediated effects of $\mathrm{PGE}_{2}$ on eosinophil effector functions. Therefore, eosinophil shape change responses with regard to the EP4-mediated effects were compared for eosinophils contained within PMNL preparations and purified eosinophils. Shape change was induced by varying concentrations of eotaxin in the presence of $\mathrm{PGE}_{2}$ $(30 \mathrm{nM})$, the EP4 receptor agonist ONO AE1-329 (30 nM), the $\mathrm{EP} 2$ receptor agonist butaprost $(1 \mu \mathrm{M})$ or the respective vehicle. As expected, the presence of neutrophil granulocytes had no effect on the EP4-mediated attenuation of eosinophil shape change (Suppl. Fig. S2A and B). Corresponding to these observations, we were able to show that neither shape change nor $\mathrm{Ca}^{2+}$ mobilization as induced by IL-8 was affected by $\mathrm{PGE}_{2}$ in neutrophils (Suppl. Fig. S2C and D).
$\mathrm{PGE}_{2}$ modulates eosinophil effector functions via EP4 receptors

Next we investigated the effect of $\mathrm{PGE}_{2}$ on eosinophil effector functions such as respiratory burst and upregulation of adhesion molecules. Purified eosinophils were mixed with varying concentrations of $\mathrm{PGE}_{2}$, the EP4 receptor agonist ONO AE1-329 (0.03-30 nM each), the EP2 receptor agonist butaprost $(30 \mathrm{nM})$ or vehicle and were then stimulated with eotaxin $(0.5-50 \mathrm{nM})$. Respiratory burst was quantified by flow cytometry. $\mathrm{PGE}_{2}$ very potently attenuated the eotaxin-induced respiratory burst, at concentrations as low as $0.3 \mathrm{nM}$, while the EP2 receptor agonist butaprost did not mimic this $\mathrm{PGE}_{2}$ effect at a concentration of $30 \mathrm{nM}$ (Fig. 6a). With a similar potency and efficacy as $\mathrm{PGE}_{2}$, the EP4 receptor agonist ONO AE1329 afforded inhibition of eosinophil respiratory burst (Fig. 6b). In further experiments, we investigated whether pretreatment with the EP4 receptor antagonists ONO AE3$208(100 \mathrm{nM})$ or GW627368X $(10 \mu \mathrm{M})$ had an influence on the $\mathrm{PGE}_{2}$-induced attenuation of the respiratory burst in 
Fig. $5 \mathrm{PGE}_{2}$ attenuates the chemoattractant-induced shape change of eosinophils via EP4 receptors.

a, b Polymorphonuclear leukocyte preparations were mixed with vehicle, $\mathrm{PGE}_{2}$, the IP/EP1 receptor agonist iloprost, the EP2 receptor agonist butaprost, the EP1/EP3 receptor agonist sulprostone or the EP4 agonist ONO AE1-329, and shape change was induced with $\mathrm{PGD}_{2}$. c, d Polymorphonuclear leukocyte preparations were pretreated with the EP4 antagonists ONO AE3-208, GW627368X or vehicle, then mixed with $\mathrm{PGE}_{2}$, ONO AE1329 or its solvent and stimulated with eotaxin. Shape change was determined with flow cytometry as increase in forward scatter. Eosinophils were distinguished from neutrophils as cells with higher auto-fluorescence.

Responses were expressed as percent of the maximum control response, i.e., in the absence of a prostanoid. Data are shown as mean \pm SEM.; $n=3-4$. $* p<0.05$ versus vehicle. ${ }^{\#} p<0.05$ versus $\mathrm{PGE}_{2}$
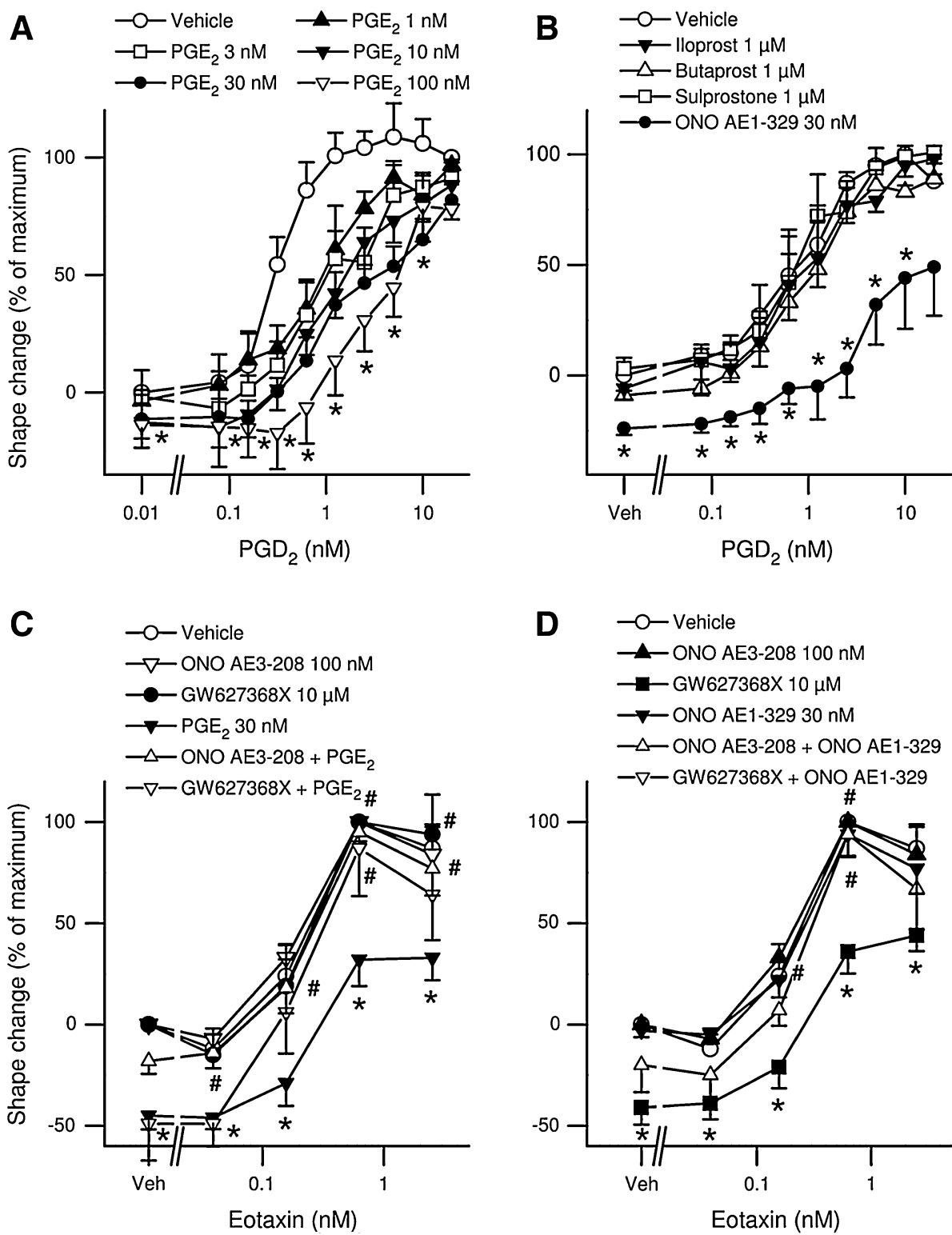

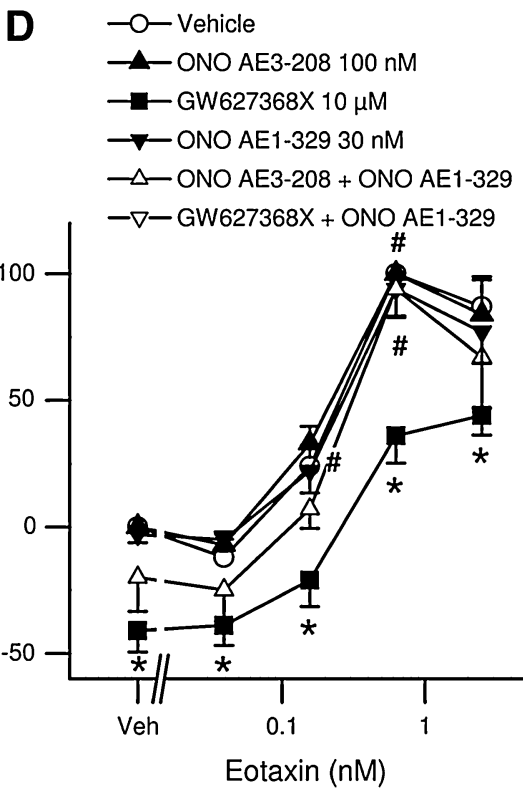

eosinophil granulocytes. Both EP4 receptor antagonists, ONO AE3-208 and GW627368X, almost completely reversed the inhibitory effect of $\mathrm{PGE}_{2}$ (Fig. 6c) and also that of the EP4 receptor agonist ONO AE1-329 (Fig. 6d).

Since the adhesion molecule $\mathrm{CD} 11 \mathrm{~b}$ is an important modulator of leukocyte responses such as migration and mediator release $[45,46]$, we also investigated the effect of $\mathrm{PGE}_{2}$ on the chemoattractant-induced upregulation of $\mathrm{CD} 11 \mathrm{~b}$ on eosinophils. To this end, cells were mixed with different concentrations of $\mathrm{PGE}_{2}(10-100 \mathrm{nM})$, the EP4 receptor agonist ONO AE1-329 $(30 \mathrm{nM})$ or vehicle and were then stimulated with $\mathrm{PGD}_{2}(5-500 \mathrm{nM})$ or eotaxin (0.3-10 nM). Cell surface expression of CD11b on eosinophils was upregulated by $\mathrm{PGD}_{2}$ and eotaxin approximately 1.5-fold, and both $\mathrm{PGE}_{2}$ and ONO AE1-329 led to a decrease of this response (Fig. 7a, b). These data indicate that $\mathrm{PGE}_{2}$ modulates eosinophil effector functions via the EP4 receptor.

EP4 receptors are expressed by infiltrating eosinophils in inflamed tissue

To investigate whether infiltrating cells in allergic airway inflammation express EP4 receptors, immunohistochemistry of human nasal polyps and allergic rhinosinusitis was performed. Epithelial cells and infiltrating leukocytes stained positive with the EP4 antibody (Fig. 8a) while sections incubated with the isotype-matched control antibody showed no staining (Fig. 8c), hence demonstrating the specificity of the EP4 antibody. The infiltrating leukocytes were also predominantly positive for eosinophil peroxidase (Fig. 8b). Double immunofluorescence staining 
Fig. $6 \mathrm{PGE}_{2}$ prevents

eosinophil respiratory burst via EP4 receptors. Purified eosinophils were mixed with $\mathrm{PGE}_{2}$, the EP2 receptor agonist butaprost (a), the EP4 receptor agonist ONO AE1-329 (b), or vehicle before respiratory burst was induced with eotaxin. c, $\mathbf{d}$ Eosinophils were pretreated with the EP4 antagonists ONO AE3-208, GW627368X or vehicle, then mixed with $\mathrm{PGE}_{2}$, ONO AE1-329 or its solvent, and stimulated with eotaxin. Respiratory burst was determined by flow cytometry as increase of fluorescence in FL-1. Responses were expressed as percent of baseline fluorescence. Data are shown as mean \pm SEM, $n=3-15$. $* p<0.05$ versus ONO AE3208. ${ }^{\#} p<0.05$ versus GW627368X
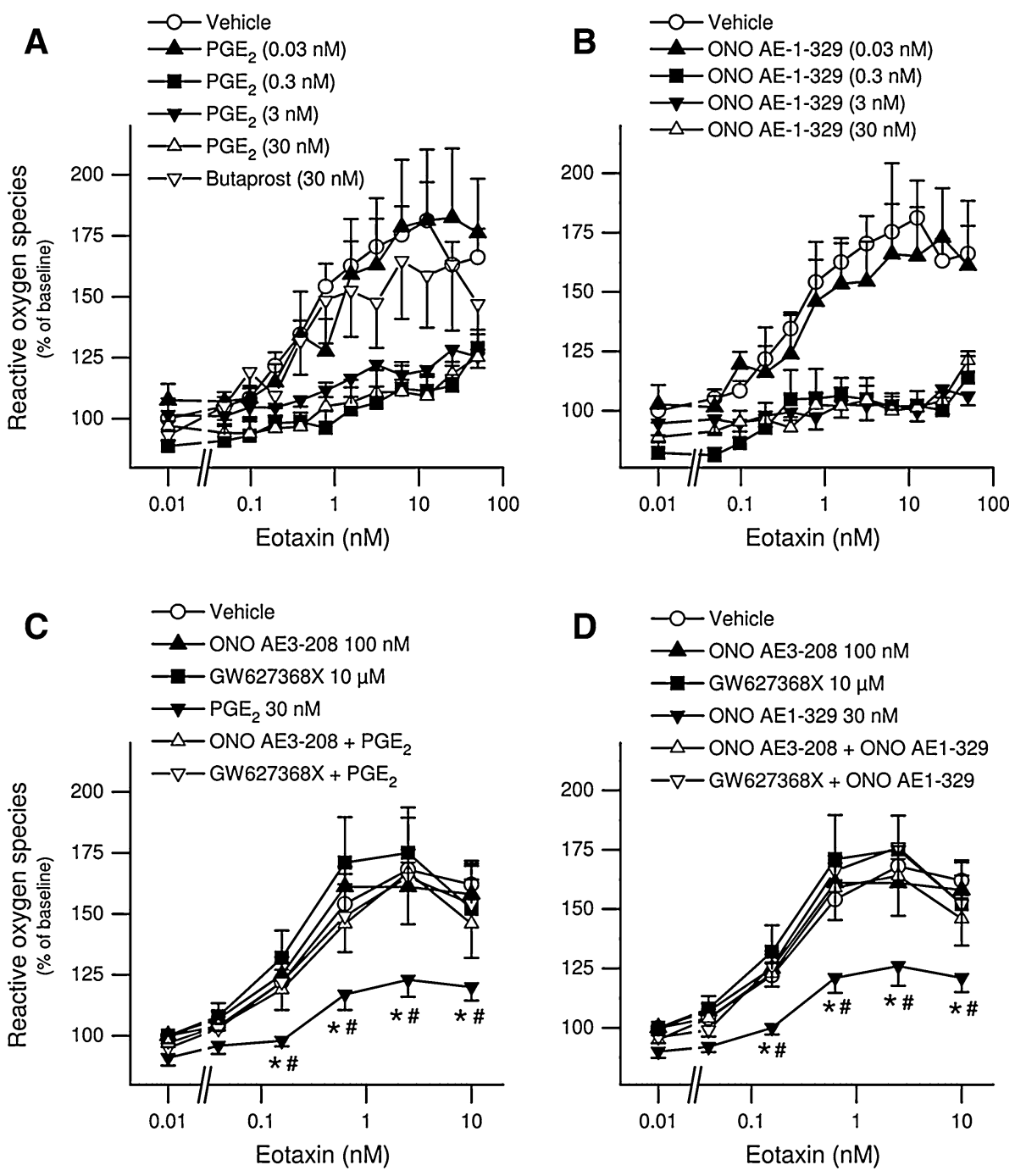

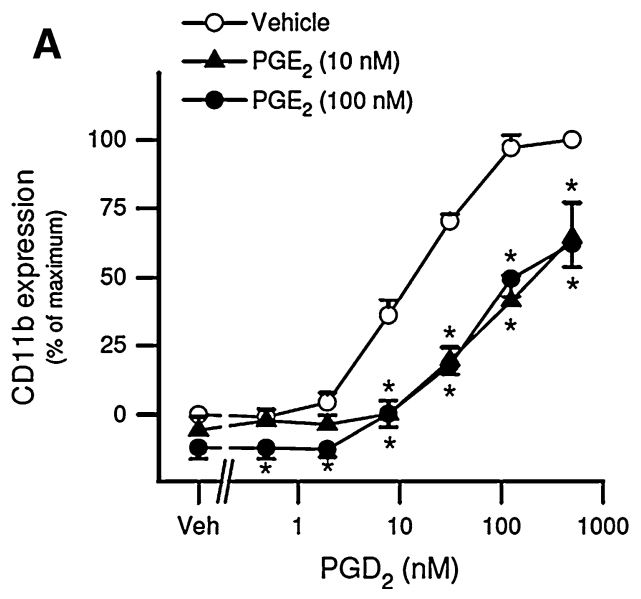

Fig. 7 Chemoattractant-induced upregulation of CD11b is modulated by $\mathrm{PGE}_{2}$ and EP4 receptors. Polymorphonuclear leukocyte preparations were mixed with vehicle, $\mathrm{PGE}_{2}$, or the EP4 agonist ONO AE1329 , and upregulation of the adhesion molecule CD11b was then stimulated with $\mathrm{PGD}_{2}$ (a) or eotaxin (b). Cell surface expression of

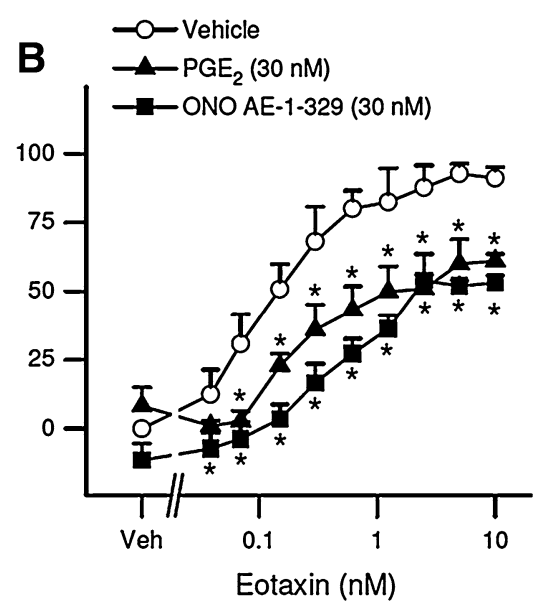

CD11b was measured with flow cytometry by direct immunofluorescence staining. Eosinophils were distinguished from neutrophils as CD16-negative cells. Responses were expressed as percent of the maximum control response, i.e., in the absence of a prostanoid. Data are shown as mean \pm SEM; $n=5-6 .{ }^{*} p<0.05$ versus vehicle 
finally indicated the presence of EP4 receptors in eosinophil peroxidase-positive cells in the tissue (Fig. 8d).

\section{Discussion}

We have recently shown that $\mathrm{PGE}_{2}$ attenuates the migration of human eosinophil granulocytes and that the EP2 receptor is involved in that effect [30]. In the current study, we report that the EP4 receptor is even more substantially involved in the regulation of eosinophil effector functions, since we demonstrate for the first time that the selective EP4 agonist
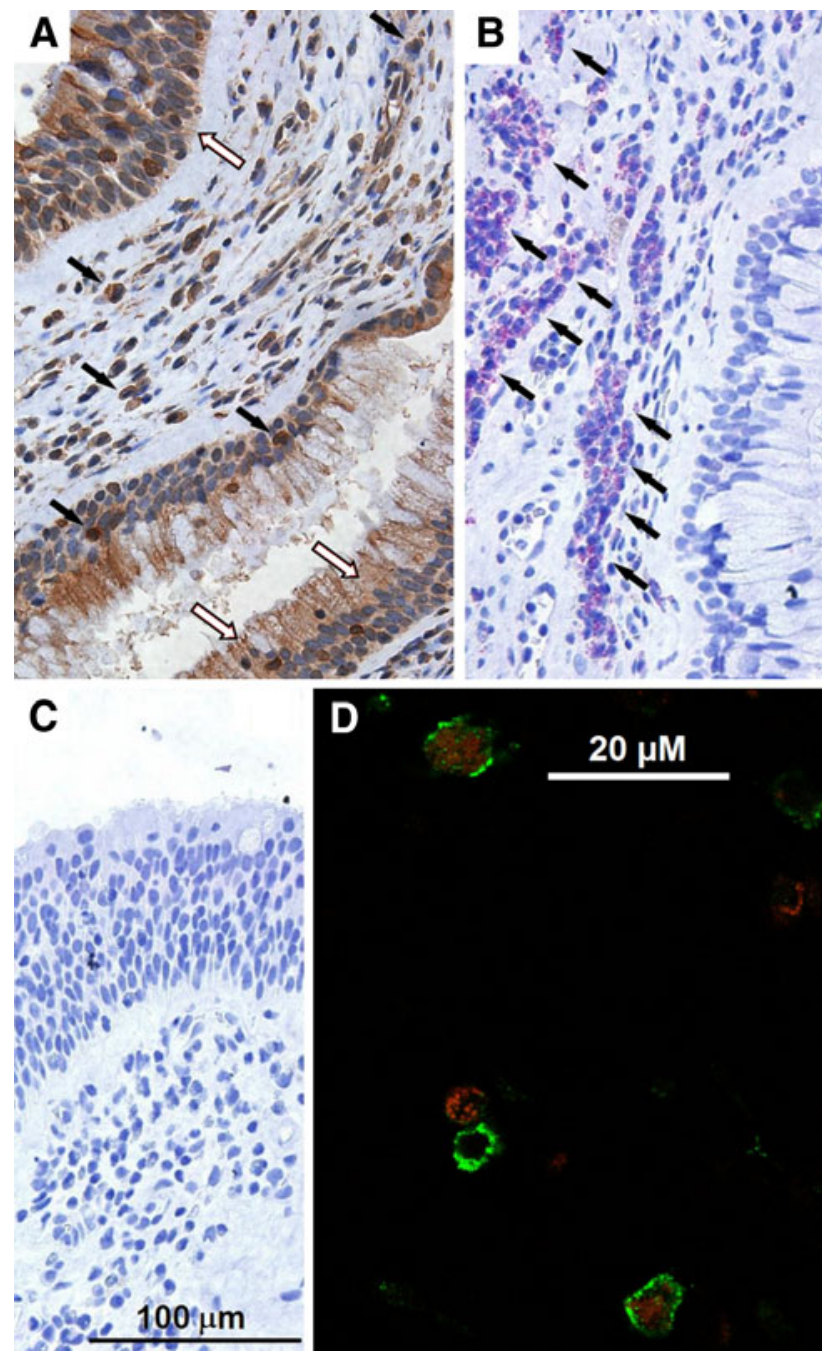

Fig. 8 Infiltrating inflammatory cells in human nasal polyps express EP4 receptors. a EP4 receptors (stained brown) were observed by immunohistochemistry in nasal epithelial cells (indicated by white arrows) and infiltrating leukocytes (black arrows). b Infiltrating leukocytes were also positive for eosinophil peroxidase. c No staining was observed with the control antibody. d Double immunofluorescence staining revealed specific co-expression of EP4 (green) and eosinophil peroxidase (red) in the majority of eosinophils. Images are representative of three polyps from different patients
ONO-AE1-329 not only abrogates eosinophil migration but also abolishes the production of reactive oxygen species, $\mathrm{Ca}^{2+}$ responses and upregulation of adhesion molecules on eosinophils. Moreover, we show that eosinophils express EP4 receptors in peripheral blood and that infiltrating leukocytes are EP4-positive in inflamed tissue. Therefore, our data suggest that pharmacological activation of EP4 receptors using subtype-selective agonists may afford attenuation of pathogenic eosinophil functions that are substantially linked to allergen-induced airway inflammation and tissue damage [47, 48].

Our data presented in the current study and recently presented data [30] suggest that both the EP2 and EP4 receptor are mediating the inhibitory effect of $\mathrm{PGE}_{2}$. Interestingly, blockade of either receptor is sufficient to largely abolish the inhibitory effect of $\mathrm{PGE}_{2}$ on the migration of eosinophils. Since the EP2 antagonist AH6809 and the EP4 antagonist GW627368X have been shown to display very low affinity for EP4 and EP2 receptors, respectively [32, 49], one possible explanation for this unexpected observation might be the cooperative signaling of these two receptors in eosinophils, e.g., by forming EP2/ EP4 heteromers. It was reported recently that the chemokine receptors CCR2, CCR5, and CXCR4 form heteromeric complexes, and specific antagonists of one receptor can lead to functional inhibition of the other heteromerization partner in vitro and in vivo [50]. The exact mechanism behind the cooperative signaling of EP2 and EP4 receptors awaits further studies. Importantly, the selective EP4 agonist ONO AE1-329 fully mimicked the inhibitory effect of $\mathrm{PGE}_{2}$ on eosinophils. In agreement with these functional responses, we could show by Western blot and flow cytometric immunostaining that human peripheral blood eosinophils express EP4 receptors. Interestingly, we found that peripheral blood eosinophils also express EP1 and EP3 receptors, as suggested previously for eosinophils recovered from sputum [51]; the role of these receptors in eosinophil function is still unclear.

EP4 receptors were also detectable on infiltrating leukocytes, presumably eosinophils, in inflamed human nasal mucosa, and also in murine lungs after allergen exposure (data not shown). In contrast, EP4 receptor expression was confined to the epithelium in the lungs of control animals. These data suggest that the amelioration of airway eosinophilia as observed after administration of $\mathrm{PGE}_{2}$ in humans and in experimental models [14, 15] might be mediated by EP4 receptors. Therefore, our data might provide the rationale for the evaluation of systemically available EP4 agonists in models of inflammation.

Stimulation of EP4 receptors usually increases intracellular cAMP levels. Interestingly, it seems that the inhibitory effect of EP4 receptor activation does not depend on activation of the adenylyl cyclase/PKA 
pathway, as the adenylyl cyclase inhibitor SQ22536 did not reverse the inhibitory effect of ONO AE1-329 on eosinophil migration. The effectiveness of SQ22536 as an adenylyl cyclase inhibitor was demonstrated by the fact that SQ22536 prevented the attenuation of eosinophil migration induced by $\mathrm{PGI}_{2}$, a known stimulator of adenylyl cyclase [52]. Stimulation of EP4 has been shown to cause phosphorylation of extracellular signal-regulated kinases (ERKs) through a PI3K-dependent mechanism [53]. Additionally, the existence of an alternative EP2/EP4 signaling pathway, linked to PKC activation has been postulated [54]. Therefore, we investigated the effect of the PI3K inhibitor LY294002 and the selective PKC inhibitor chelerythrine on eosinophil migration in the presence of the EP4 receptor agonist ONO AE1-329. In fact, inhibition of PI3K prevented the inhibition of eosinophil migration induced by ONO AE1-329. Moreover, exposure of eosinophils to the selective PKC inhibitor chelerythrine prior to stimulation of the EP4 receptor with ONO AE1-329 resulted in almost complete reversal of the attenuation of eosinophil chemotaxis. Since these data implicated PKC as a negative regulator of eosinophil migration, we investigated the effect of the PKC activator PMA on eosinophil migration. As expected, PMA very potently mimicked the inhibitory effect of $\mathrm{PGE}_{2}$ and the EP4 receptor agonist on eosinophil migration. The inhibitory effect of PMA, however, could not be prevented by the PI3K inhibitor LY294002. Therefore, our data indicate that both PI3K and PKC are involved in the attenuation of eosinophil migration upon EP4 receptor activation and confirm previous data that modulation of PI3K mediates the inhibitory effect of $\mathrm{PGE}_{2}$ in neutrophils [55].

Chemoattractants like $\mathrm{PGD}_{2}$ or eotaxin are known to elevate intracellular $\mathrm{Ca}^{2+}$ concentrations in eosinophils, which is an essential requirement for effector functions like degranulation and respiratory burst [43]. Hence, we investigated the influence of $\mathrm{PGE}_{2}$ on the $\mathrm{Ca}^{2+}$ mobilization induced by these chemoattractants. Our data show that $\mathrm{PGE}_{2}$ inhibits chemoattractant-induced $\mathrm{Ca}^{2+}$ influx in eosinophils, and what is more, that this effect is mediated via EP4 receptors. This conclusion was based on the observations that the selective EP4 agonist ONO AE1-329 likewise inhibited eosinophil $\mathrm{Ca}^{2+}$ responses and that this effect was reversed in the presence of the selective EP4 receptor antagonist ONO AE3-208. In contrast, the $\mathrm{PGE}_{2^{-}}$ induced attenuation of $\mathrm{Ca}^{2+}$ flux in eosinophils was not mimicked by the IP/EP1 receptor agonist iloprost, the EP2 receptor agonist butaprost, or the EP1/EP3 receptor agonist sulprostone. Another important prerequisite for chemoattractant-induced eosinophil migration, oxidative burst, and degranulation is the rapid reorganization of the cytoskeleton, which results in a shape change of the cells [43]. Similar to our observation with $\mathrm{Ca}^{2+}$ mobilization we found that $\mathrm{PGE}_{2}$ inhibits shape change of eosinophils solely by EP4 receptors, since inhibition of shape change could also be evoked with ONO AE1-329 but not with iloprost, butaprost, or sulprostone. This notion was supported by the fact that inhibition of eosinophil shape change induced by $\mathrm{PGE}_{2}$ or ONO AE1-329 was reversed by the EP4 receptor antagonists ONO AE3-208 and GW627368X in a similar fashion.

Interestingly, neither chelerythrine nor LY294002 was able to reverse the inhibitory effect of the EP4 agonist on $\mathrm{Ca}^{2+}$ flux and shape change (unpublished observation), suggesting that the roles of PI3K and PKC are largely restricted to EP4-mediated inhibition of chemotaxis. This notion complements our finding that both EP2 and EP4 activation curtails eosinophil chemotaxis, while only EP4 controls shape change, $\mathrm{Ca}^{2+}$ flux, and production of reactive oxygen species. Therefore, a detailed analysis of EP4related signaling needs to be carried out for each eosinophil function separately in future studies.

Since $\mathrm{Ca}^{2+}$ mobilization and shape change are important requirements for eosinophil adhesion, respiratory burst, and mediator release, we investigated the consequences of reduced $\mathrm{Ca}^{2+}$ responses by $\mathrm{PGE}_{2}$ with regard to these eosinophil effector functions. Indeed we found that the eotaxin- and $\mathrm{PGD}_{2}$-induced stimulation of $\mathrm{CD} 11 \mathrm{~b}$ expression was negatively modulated in the presence of $\mathrm{PGE}_{2}$ in eosinophils, and that this effect could be mimicked by the EP4 receptor agonist ONO AE1-329. In contrast to other adhesion molecules, cell surface expression of CD11b is rapidly increased on leukocytes after stimulation [56]. The $\beta_{2}$-integrin CD11b/CD18 (also referred to as CR3, Mac-1, or $\left.\alpha_{\mathrm{m}} \beta_{2}\right)$ is an important complement receptor that binds multiple ligands, including C3bi, ICAM-1, fibrinogen, and $\beta$-glucan. Apart from adhesion, CD11b/CD18 is an important modulator of further leukocyte responses, including migration [45], respiratory burst [57], degranulation [58], and apoptosis [59]. CD11b expression on circulating eosinophils is significantly elevated in various allergic disorders, including atopic dermatitis and bronchial asthma [60, 61]. Therefore, upregulation of surface CD11b closely reflects eosinophil activation and might be a prerequisite of leukocyte recruitment to sites of inflammation, by mediating the release of eosinophils from bone marrow [62] and their migration [63]. These observations suggest that the reduced $\mathrm{CD} 11 \mathrm{~b}$ response in the presence of $\mathrm{PGE}_{2}$ might have a profound impact on eosinophil functions, such as migration to sites of allergic reactions, degranulation, and oxidative burst. In agreement with this notion, we were able to show that $\mathrm{PGE}_{2}$ and the EP4 receptor agonist ONO AE1329 attenuate the formation of reactive oxygen species with remarkably high potency, while the EP2 agonist butaprost had no effect. Therefore, it appears that the $\mathrm{PGE}_{2}$-induced attenuation of eosinophil oxidative burst is also mediated 
via the EP4 receptor rather than the EP2 receptor. This notion was further asserted by the EP4 receptor antagonist ONO AE3-208 and GW627368X, which reversed the inhibition of reactive oxygen species production by $\mathrm{PGE}_{2}$ and ONO AE1-329.

In conclusion, the present study shows that eosinophils express EP4 receptors and activation of EP4 receptors negatively modulates eosinophil migration and respiratory burst. Furthermore, we were able to show that PI3K and PKC are involved in the inhibitory effect of EP4 receptors. In previous studies it was shown that $\mathrm{PGE}_{2}$ has bronchoprotective and anti-inflammatory properties but the usefulness of $\mathrm{PGE}_{2}$ as a therapeutic agent is limited because of its various side-effects such as acute bronchoconstriction, retrosternal soreness, transient cough, and flu-like symptoms $[10,11,14]$. While the latter effects of $\mathrm{PGE}_{2}$ are thought to arise from EP1 or EP3 receptor stimulation, selective EP4 agonists might have more favorable pharmacological profiles. Therefore, EP4 agonists might be a useful novel approach in the treatment of eosinophilic diseases as they not only attenuate chemoattractant-induced eosinophil migration and degranulation, as EP2 receptor agonists do, but also abolish other eosinophil effector functions such as upregulation of adhesion molecules or production of reactive oxygen species.

Acknowledgments V. K. and S. P. were funded by the Ph. D. Program Molecular Medicine of the Medical University of Graz. This work was supported by the Jubiläumsfonds of the Austrian National Bank (Grants 11967 and 13487), the Austrian Science Fund FWF (Grants P19424-B05, P22521-B18 and P21004-B02), and the Franz Lanyar Foundation (Grants 315, 316, and 343). A. H. has received research support and consultancy fees from AstraZeneca and Almirall.

Open Access This article is distributed under the terms of the Creative Commons Attribution Noncommercial License which permits any noncommercial use, distribution, and reproduction in any medium, provided the original author(s) and source are credited.

\section{References}

1. Woerly G, Roger N, Loiseau S, Capron M (1999) Expression of Th1 and Th2 immunoregulatory cytokines by human eosinophils. Int Arch Allergy Immunol 118:95-97

2. Navarro S, Aleu J, Jimenez M, Boix E, Cuchillo CM, Nogues MV (2008) The cytotoxicity of eosinophil cationic protein/ribonuclease 3 on eukaryotic cell lines takes place through its aggregation on the cell membrane. Cell Mol Life Sci 65:324-337

3. Aceves SS, Broide DH (2008) Airway fibrosis and angiogenesis due to eosinophil trafficking in chronic asthma. Curr Mol Med $8: 350-358$

4. Green RH, Brightling CE, McKenna S, Hargadon B, Parker D, Bradding P, Wardlaw AJ, Pavord ID (2002) Asthma exacerbations and sputum eosinophil counts: a randomised controlled trial. Lancet 360:1715-1721
5. Foster PS, Rosenberg HF, Asquith KL, Kumar RK (2008) Targeting eosinophils in asthma. Curr Mol Med 8:585-590

6. Straumann A, Simon HU (2005) Eosinophilic esophagitis: escalating epidemiology? J Allergy Clin Immunol 115:418-419

7. Wedemeyer J, Vosskuhl K (2008) Role of gastrointestinal eosinophils in inflammatory bowel disease and intestinal tumours. Best Pract Res Clin Gastroenterol 22:537-549

8. Simon D, Simon HU (2007) Eosinophilic disorders. J Allergy Clin Immunol 119:1291-1300

9. Smith AP, Cuthbert MF, Dunlop LS (1975) Effects of inhaled prostaglandins E1, E2, and F2alpha on the airway resistance of healthy and asthmatic man. Clin Sci Mol Med 48:421-430

10. Pavord ID, Wong CS, Williams J, Tattersfield AE (1993) Effect of inhaled prostaglandin E2 on allergen-induced asthma. Am Rev Respir Dis 148:87-90

11. Mathe AA, Hedqvist P (1975) Effect of prostaglandins F2 alpha and $\mathrm{E} 2$ on airway conductance in healthy subjects and asthmatic patients. Am Rev Respir Dis 111:313-320

12. Costello JF, Dunlop LS, Gardiner PJ (1985) Characteristics of prostaglandin induced cough in man. Br J Clin Pharmacol 20: 355-359

13. Roberts AM, Schultz HD, Green JF, Armstrong DJ, Kaufman MP, Coleridge HM, Coleridge JC (1985) Reflex tracheal contraction evoked in dogs by bronchodilator prostaglandins E2 and I2. J Appl Physiol 58:1823-1831

14. Gauvreau GM, Watson RM, O’Byrne PM (1999) Protective effects of inhaled PGE2 on allergen-induced airway responses and airway inflammation. Am J Respir Crit Care Med 159:31-36

15. Martin JG, Suzuki M, Maghni K, Pantano R, Ramos-Barbon D, Ihaku D, Nantel F, Denis D, Hamid Q, Powell WS (2002) The immunomodulatory actions of prostaglandin E2 on allergic airway responses in the rat. J Immunol 169:3963-3969

16. Adcock JJ, Garland LG, Moncada S, Salmon JA (1978) Enhancement of anaphylactic mediator release from guinea-pig perfused lungs by fatty acid hydroperoxides. Prostaglandins 16:163-177

17. Teixeira MM, Williams TJ, Hellewell PG (1993) E-type prostaglandins enhance local oedema formation and neutrophil accumulation but suppress eosinophil accumulation in guinea-pig skin. Br J Pharmacol 110:416-422

18. Moore BB, Ballinger MN, White ES, Green ME, Herrygers AB, Wilke CA, Toews GB, Peters-Golden M (2005) Bleomycininduced $\mathrm{E}$ prostanoid receptor changes alter fibroblast responses to prostaglandin E2. J Immunol 174:5644-5649

19. Gavett SH, Madison SL, Chulada PC, Scarborough PE, Qu W, Boyle JE, Tiano HF, Lee CA, Langenbach R, Roggli VL, Zeldin DC (1999) Allergic lung responses are increased in prostaglandin $\mathrm{H}$ synthase-deficient mice. J Clin Invest 104:721-732

20. Nakata J, Kondo M, Tamaoki J, Takemiya T, Nohara M, Yamagata K, Nagai A (2005) Augmentation of allergic inflammation in the airways of cyclooxygenase-2-deficient mice. Respirology 10:149-156

21. Peebles RS Jr, Hashimoto K, Morrow JD, Dworski R, Collins RD, Hashimoto Y, Christman JW, Kang KH, Jarzecka K, Furlong J, Mitchell DB, Talati M, Graham BS, Sheller JR (2002) Selective cyclooxygenase- 1 and -2 inhibitors each increase allergic inflammation and airway hyperresponsiveness in mice. Am J Respir Crit Care Med 165:1154-1160

22. Kita H, Abu-Ghazaleh RI, Gleich GJ, Abraham RT (1991) Regulation of Ig-induced eosinophil degranulation by adenosine 3',5'-cyclic monophosphate. J Immunol 146:2712-2718

23. Berends C, Dijkhuizen B, de Monchy JG, Dubois AE, Gerritsen J, Kauffman HF (1997) Inhibition of PAF-induced expression of $\mathrm{CD} 11 \mathrm{~b}$ and shedding of L-selectin on human neutrophils and eosinophils by the type IV selective PDE inhibitor, rolipram. Eur Respir J 10:1000-1007 
24. Peacock CD, Misso NL, Watkins DN, Thompson PJ (1999) PGE 2 and dibutyryl cyclic adenosine monophosphate prolong eosinophil survival in vitro. J Allergy Clin Immunol 104:153-162

25. Alam R, Dejarnatt A, Stafford S, Forsythe PA, Kumar D, Grant JA (1993) Selective inhibition of the cutaneous late but not immediate allergic response to antigens by misoprostol, a PGE analog. Results of a double-blind, placebo-controlled randomized study. Am Rev Respir Dis 148:1066-1070

26. Sugimoto Y, Narumiya S (2007) Prostaglandin E receptors. J Biol Chem 282:11613-11617

27. Sheller JR, Mitchell D, Meyrick B, Oates J, Breyer R (2000) $\mathrm{EP}(2)$ receptor mediates bronchodilation by $\mathrm{PGE}(2)$ in mice. J Appl Physiol 88:2214-2218

28. Negishi M, Hasegawa H, Ichikawa A (1996) Prostaglandin E receptor EP3gamma isoform, with mostly full constitutive $\mathrm{Gi}$ activity and agonist-dependent Gs activity. FEBS Lett 386: $165-168$

29. Di Cesare A, Del Piccolo P, Zacchetti D, Grohovaz F (2006) EP2 receptor stimulation promotes calcium responses in astrocytes via activation of the adenylyl cyclase pathway. Cell Mol Life Sci 63:2546-2553

30. Sturm EM, Schratl P, Schuligoi R, Konya V, Sturm GJ, Lippe IT, Peskar BA, Heinemann A (2008) Prostaglandin E2 inhibits eosinophil trafficking through E-prostanoid 2 receptors. J Immunol 181:7273-7283

31. Suzawa T, Miyaura C, Inada M, Maruyama $T$, Sugimoto $Y$, Ushikubi F, Ichikawa A, Narumiya S, Suda T (2000) The role of prostaglandin E receptor subtypes (EP1, EP2, EP3, and EP4) in bone resorption: an analysis using specific agonists for the respective EPs. Endocrinology 141:1554-1559

32. Wilson RJ, Giblin GM, Roomans S, Rhodes SA, Cartwright KA, Shield VJ, Brown J, Wise A, Chowdhury J, Pritchard S, Coote J, Noel LS, Kenakin T, Burns-Kurtis CL, Morrison V, Gray DW, Giles H (2006) GW627368X ((N-\{2-[4-(4, 9-diethoxy-1-oxo-1, 3-dihydro-2H-benzo[f]isoindol-2-yl)phenyl] acetyl $\}$ benzene sulphonamide): a novel, potent and selective prostanoid EP4 receptor antagonist. Br J Pharmacol 148:326-339

33. Kabashima K, Saji T, Murata T, Nagamachi M, Matsuoka T, Segi E, Tsuboi K, Sugimoto Y, Kobayashi T, Miyachi Y, Ichikawa A, Narumiya S (2002) The prostaglandin receptor EP4 suppresses colitis, mucosal damage and CD4 cell activation in the gut. J Clin Invest 109:883-893

34. Hartnell A, Heinemann A, Conroy DM, Wait R, Sturm GJ, Caversaccio M, Jose PJ, Williams TJ (2004) Identification of selective basophil chemoattractants in human nasal polyps as insulin-like growth factor-1 and insulin-like growth factor-2. J Immunol 173:6448-6457

35. Schuligoi R, Schmidt R, Geisslinger G, Kollroser M, Peskar BA, Heinemann A (2007) PGD2 metabolism in plasma: kinetics and relationship with bioactivity on DP1 and CRTH2 receptors. Biochem Pharmacol 74:107-117

36. Royer JF, Schratl P, Lorenz S, Kostenis E, Ulven T, Schuligoi R, Peskar BA, Heinemann A (2007) A novel antagonist of CRTH2 blocks eosinophil release from bone marrow, chemotaxis and respiratory burst. Allergy 62:1401-1409

37. Heinemann A, Ofner M, Amann R, Peskar BA (2003) A novel assay to measure the calcium flux in human basophils: effects of chemokines and nerve growth factor. Pharmacology 67:49-54

38. Steinbrunn T, Stuhmer T, Gattenlohner S, Rosenwald A, Mottok A, Unzicker C, Einsele H, Chatterjee M, Bargou RC (2010) Mutated RAS and constitutively activated Akt delineate distinct oncogenic pathways, which independently contribute to multiple myeloma cell survival. Blood 117(6):1998-2004

39. Han C, Wu T (2005) Cyclooxygenase-2-derived prostaglandin E2 promotes human cholangiocarcinoma cell growth and invasion through EP1 receptor-mediated activation of the epidermal growth factor receptor and Akt. J Biol Chem 280:24053-24063

40. Caristi S, Piraino G, Cucinotta M, Valenti A, Loddo S, Teti D (2005) Prostaglandin E2 induces interleukin-8 gene transcription by activating C/EBP homologous protein in human $\mathrm{T}$ lymphocytes. J Biol Chem 280:14433-14442

41. Stubbs VE, Schratl P, Hartnell A, Williams TJ, Peskar BA, Heinemann A, Sabroe I (2002) Indomethacin causes prostaglandin $\mathrm{D}(2)$-like and eotaxin-like selective responses in eosinophils and basophils. J Biol Chem 277:26012-26020

42. Schratl P, Sturm EM, Royer JF, Sturm GJ, Lippe IT, Peskar BA, Heinemann A (2006) Hierarchy of eosinophil chemoattractants: role of p38 mitogen-activated protein kinase. Eur J Immunol 36:2401-2409

43. Schratl P, Heinemann A (2009) Differential involvement of $\mathrm{Ca}^{2+}$ and actin filament in leukocyte shape change. Pharmacology 83:131-140

44. Heinemann A, Schuligoi R, Sabroe I, Hartnell A, Peskar BA (2003) Delta12-prostaglandin J2, a plasma metabolite of prostaglandin D2, causes eosinophil mobilization from the bone marrow and primes eosinophils for chemotaxis. J Immunol 170: 4752-4758

45. Rainger GE, Buckley C, Simmons DL, Nash GB (1997) Crosstalk between cell adhesion molecules regulates the migration velocity of neutrophils. Curr Biol 7:316-325

46. Couturier C, Haeffner-Cavaillon N, Weiss L, Fischer E, Kazatchkine MD (1990) Induction of cell-associated interleukin 1 through stimulation of the adhesion-promoting proteins LFA-1 (CD11a/CD18) and CR3 (CD11b/CD18) of human monocytes. Eur J Immunol 20:999-1005

47. Bousquet J, Chanez P, Lacoste JY, Barneon G, Ghavanian N, Enander I, Venge P, Ahlstedt S, Simony-Lafontaine J, Godard P et al (1990) Eosinophilic inflammation in asthma. N Engl J Med 323:1033-1039

48. Jacobsen EA, Taranova AG, Lee NA, Lee JJ (2007) Eosinophils: singularly destructive effector cells or purveyors of immunoregulation? J Allergy Clin Immunol 119:1313-1320

49. Abramovitz M, Adam M, Boie Y, Carriere M, Denis D, Godbout C, Lamontagne S, Rochette C, Sawyer N, Tremblay NM, Belley M, Gallant M, Dufresne C, Gareau Y, Ruel R, Juteau H, Labelle M, Ouimet N, Metters KM (2000) The utilization of recombinant prostanoid receptors to determine the affinities and selectivities of prostaglandins and related analogs. Biochim Biophys Acta 1483: 285-293

50. Sohy D, Yano H, de Nadai P, Urizar E, Guillabert A, Javitch JA, Parmentier M, Springael JY (2009) Hetero-oligomerization of CCR2, CCR5, and CXCR4 and the protean effects of "selective" antagonists. J Biol Chem 284:31270-31279

51. Ying S, O'Connor BJ, Meng Q, Woodman N, Greenaway S, Wong H, Mallett K, Lee TH, Corrigan C (2004) Expression of prostaglandin $\mathrm{E}(2)$ receptor subtypes on cells in sputum from patients with asthma and controls: effect of allergen inhalational challenge. J Allergy Clin Immunol 114:1309-1316

52. Sugama K, Tanaka T, Yokohama H, Negishi M, Hayashi H, Ito S, Hayaishi O (1989) Stimulation of cAMP formation by prostaglandin D2 in primary cultures of bovine adrenal medullary cells: identification of the responsive population as fibroblasts. Biochim Biophys Acta 1011:75-80

53. Fujino H, Xu W, Regan JW (2003) Prostaglandin E2-induced functional expression of early growth response factor-1 by EP4, but not EP2, prostanoid receptors via the phosphatidylinositol 3-kinase and extracellular signal-regulated kinases. J Biol Chem 278:12151-12156

54. Reno F, Cannas M (2005) Effect of prostaglandin E2 on PMAinduced macrophage differentiation. Prostaglandins Other Lipid Mediat 75:13-24 
55. Burelout C, Thibault N, Levasseur S, Simard S, Naccache PH, Bourgoin SG (2004) Prostaglandin E2 inhibits the phospholipase D pathway stimulated by formyl-methionyl-leucyl-phenylalanine in human neutrophils. Involvement of EP2 receptors and phosphatidylinositol 3-kinase gamma. Mol Pharmacol 66:293-301

56. Walker C, Rihs S, Braun RK, Betz S, Bruijnzeel PL (1993) Increased expression of $\mathrm{CD} 11 \mathrm{~b}$ and functional changes in eosinophils after migration across endothelial cell monolayers. J Immunol 150:4061-4071

57. Nathan C, Srimal S, Farber C, Sanchez E, Kabbash L, Asch A, Gailit J, Wright SD (1989) Cytokine-induced respiratory burst of human neutrophils: dependence on extracellular matrix proteins and CD11/CD18 integrins. J Cell Biol 109:1341-1349

58. Richter J, Ng-Sikorski J, Olsson I, Andersson T (1990) Tumor necrosis factor-induced degranulation in adherent human neutrophils is dependent on CD11b/CD18-integrin-triggered oscillations of cytosolic free Ca2+. Proc Natl Acad Sci USA 87:9472-9476

59. Rubel C, Gomez S, Fernandez GC, Isturiz MA, Caamano J, Palermo MS (2003) Fibrinogen-CD11b/CD18 interaction activates the NF-kappa B pathway and delays apoptosis in human neutrophils. Eur J Immunol 33:1429-1438

60. Barthel SR, Jarjour NN, Mosher DF, Johansson MW (2006) Dissection of the hyperadhesive phenotype of airway eosinophils in asthma. Am J Respir Cell Mol Biol 35:378-386

61. Yamada H, Kurashimo S, Chihara J, Matsukura M, Yudate T, Tezuka T (1999) Overexpression of CD11b on eosinophils in atopic dermatitis: downregulation by cyclosporin A and upregulation by interleukin 5. Int Arch Allergy Immunol 120(Suppl 1):100-103

62. Palframan RT, Collins PD, Severs NJ, Rothery S, Williams TJ, Rankin SM (1998) Mechanisms of acute eosinophil mobilization from the bone marrow stimulated by interleukin 5: the role of specific adhesion molecules and phosphatidylinositol 3-kinase. J Exp Med 188:1621-1632

63. Ebisawa M, Bochner BS, Georas SN, Schleimer RP (1992) Eosinophil transendothelial migration induced by cytokines. I. Role of endothelial and eosinophil adhesion molecules in IL-1 beta-induced transendothelial migration. J Immunol 149:40214028 